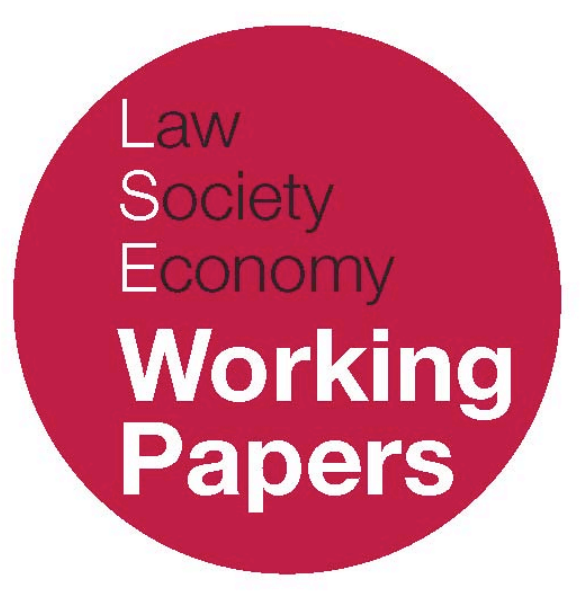

\title{
Increasing Returns in the Patent System: \\ Institutional Sources and Consequences for law
}

\author{
Sivaramjani Thambisetty \\ LSE Law, Society and Economy Working Papers 7/2009 \\ London School of Economics and Political Science \\ Law Department
}

This paper can be downloaded without charge from LSE Law, Society and Economy Working Papers at: www.lse.ac.uk/collections/law/wps/wps.htm and the Social Sciences Research Network electronic library at: http://ssrn.com/abstract=1344761.

(C) Sivaramjani Thambisetty. Users may download and/or print one copy to facilitate their private study or for non-commercial research. Users may not engage in further distribution of this material or use it for any profit-making activities or any other form of commercial gain. 


\title{
Increasing Returns in the Patent System: Institutional Sources and Consequences for law
}

\author{
Sivaramjani Thambisetty ${ }^{*}$
}

\begin{abstract}
This paper critically analyses the impact of the institutional set up of UK and US patent systems on the optimality of patent law. Based on recent work on institutionalism, the author argues that the patent system is subject to increasing returns processes or positive feedback, where the probability of further steps along a given legal sequence increases with each move down that path. In an analysis that puts temporality at the heart of the argument, this paper shows how the interactions between key institutions in the patent system can result in doctrinal incoherence. Prominent sources of increasing returns in the patent system are interinstitutional linkages, legal authority exercised by prominent institutions and the intrinsic and extrinsic uncertainty associated with patents. The inadequacy of corrective mechanisms intensifies increasing returns. In such circumstances even early or tentative commitments made to policies and legal standards become tenacious while the costs of policy reversal grow and grow and become prohibitive. The result is a legal system plagued by the possibility of bizarre and unpredictable outcomes.
\end{abstract}

\section{INTRODUCTION}

It is common, and increasingly so, to encounter absurd patent law doctrine in European and US law. Seemingly simple language in statutes can give rise to convoluted and exceptional interpretations. Thus in Europe 'animal varieties' are excluded from patentability, but this does not mean that animals cannot be patented. Computer programs 'as such' are not inventions, but there are at least

\footnotetext{
* I am grateful for valuable feedback received from Professors David Vaver, Paul David and Julia Black. I thank Hazel Moir, Kenneth Shadlen, Sebastian Haunss and other participants of the 2008 ECPR Joint Sessions Workshop on The Politics of IP for their incisive comments on this paper. Dev Gangjee, Nico Krisch and Professors Neil Duxbury and Hugh Collins also provided valuable comments.
} 
four interpretations of the phrase in UK and European case law. Discoveries are not patentable, but biological materials as the basis of biotechnological inventions are commonly patentable.

Each of these interpretations are supported by functionalist explanations $-\mathrm{Y}$ is patentable because of $\mathrm{X}$. However for a long-term observer of the patent system, the quotidian occurrence of such interpretations suggest that functional explanations are not the only possible ones. Given the possibility of alternate legitimate and viable interpretations it is no longer valid to assume the relative efficiency of patent law doctrine. If we went back and took a look at the emergence and sequential development of some of these doctrines, what would we see?

The patent system presents many unusual features that impact on the interpretation and stability of law. This chapter argues that interpretive processes in the patent system are subject to increasing returns, self-reinforcing or positive feedback processes where "the probability of further steps along the same path increases with each move down that path. ${ }^{1}$ Increasing returns is generated by institutions in the patent system where consensual goals and criteria are scant, and decisionmaking is knowledge intense and complex. The resulting distortion in substantive otutcomes and explains many of the absurd interpretations seen in this field of law. Not just single institutions but also clusters of institutions function in a way that either perpetuates or aggravates initially created advantages or disadvantages. What follows illustrates explicitly and implicitly at least four different dimensions of institutions - cognitive, regulative, normative and resource implications. The focus in this paper is on legal doctrine - where and how it emerges in the patent system and on the actors who, through the formal and informal processes either facilitate or constrain its evolution.

It has been argued strongly that the basic concept within the social sciences should be that of supple explanatory mechanisms rather than a theory. ${ }^{2}$ This paper isolates mechanisms in the patent system that due to their repeatability, have more normative relevance to patent law doctrine than existing theoretical approaches ${ }^{3}$

\footnotetext{
${ }^{1}$ P. Pierson, 'Increasing Returns, Path Dependence, and the Study of Politics' 94 American Political Science Review 251, 252 [Hereafter Pierson 'Increasing Returns'].

2 Sociologist Robert Merton's attempts in the 1960s to locate a middle ground between social laws and description led to the notion of 'mechanisms'. See J. Elster, The Cement of Society: A Study of Social Order (Cambridge: Cambridge University Press, 1989). Arthur Stinchcombe provides a discussion of the benefits and limits of the quest for mechanisms in 'The Conditions of Fruitfulness of Theorising About Mechanisms in Social Science' (1991) 21 Phil Soc Sci 367. He defines them as: '.. bits of theory about entities at a different level (e.g., individuals) than the main entities being theorised about (e.g., groups), which serve to make the higher level theory more supple, more accurate, or more general.' Also see P. Hedstrom and R. Swedberg, 'Social Mechanisms: An Introductory Essay' in P. Hedstrom and R. Swedberg (eds), Social Mechanisms (Cambridge: Cambridge University Press, 1998).

3 A major portion of patent law scholarship rests on theoretical explanations and justifications that are free-standing and do not necessarily contradict each other - a general characteristic of the study of the nature of property. James Harris for example, addresses the institutional design of property in terms of a 'mix of property-specific-justice reasons'; the alternative single-track explanations of the nature and normative foundations of property reveal sensitive questions on which there is no political or philosophical consensus. See J.W. Harris, Property and Justice (Oxford: Clarendon Press, 1996) and J.W. Harris, 'Inheritance and the Justice Tribunal' in S. Munzer (ed), New Essays in the Legal and Political Theory of
} 
which are frequently hampered by demands for predictability. ${ }^{4}$ The broad aim of this paper is therefore to explore the middle ground between patent law theory and empirical descriptions.

\section{WHY INCREASING RETURNS?}

For some theorists increasing returns are one kind of path dependence, for others it is a source of path dependence. ${ }^{5}$ Increasing returns captures the central element of path dependence, namely timing and sequence. The explicatory value of analysts' use of increasing returns processes is based on the idea that it is not only what happens that is important but also when it happens. Thus:

Increasing returns are the tendency for that which is ahead to get further ahead, for that which loses advantage to lose further advantage. They are mechanisms of positive feedback that operate - within markets, businesses, and industries to reinforce that which gains success or to aggravate that which suffers loss. Increasing returns generate not equilibrium but instability. ${ }^{6}$

Patentability in the US and European patent system lend themselves to a study of timing and sequence due to the large number of institutions involved in formal and informal law making. In the early stages when a new or immature technology is introduced there is often a period of openness, unlike the usual closed style of interpretation that is common in $\mathrm{law}^{7}$ aided in part by the level of generality in most patent legislations. ${ }^{8}$ During this period of openness more than one viable standard of patentability may be suggested. ${ }^{9}$ In processes subject to increasing

Property (Cambridge: Cambridge University Press, 2001) 106.

4 The value of an economic theory that can predict the outcome of individual patent cases in terms of efficiency, lies in the correlation between individual outcomes and net benefit to the overall system. See S. Oddi, 'Un-Unified Economic Theories of Patents: The Not Quite Holy Grail' (1996) 71 Notre D L Rev 267. Also see M. Grady and J. Alexander, 'Patent Law and Rent Dissipation' (1992) 78 Va L Rev 305 and R.P. Merges, 'Rent Control in the Patent District: Observations on the Grady-Alexander Thesis' (1992) 78 Va L Rev 359.

5 The variety of contexts in which path dependence is used has led to doubts about the analytically relevant boundary of this notion leading in turn to robust efforts to reclaim its value. See in particular P.A. David 'Path Dependence, its Critics and the Quest for "Historical Economics"' in P. Garrouste and S. Ioannides (eds) Evolution and Path Dependence in Economic Ideas: Past and Present (Cheltenham: Edward Elgar, 2001) 15.

${ }^{6}$ B. Arthur, 'Increasing Returns and the New World of Business' Harvard Business Review July-Aug 1996.

7 B. Sherman, 'Patent Law in a Time of Change: Non obviousness in Biotechnology' (1990) 10 Oxford J of Legal Stud 278.

8 Janicke notes that the broad terms used in patent statutes, rather than any perceived doctrinal inconsistency, is the chief cause of unpredictability (in CAFC decisions). P.M Janicke 'On the Causes of Unpredictability of Federal Circuit Decisions in Patent Cases' 2005 Northwestern J of 'Technology and Intellectual Property 93.

9 For example, gene sequences, as an unprecedented class of inventions could have been held unpatentable as discoveries; or for being non-commercialisable on ethical grounds; or have been held unpatentable for being 'informational' instead of physical macromolecules. All of these were valid 
returns, each of these relevant standards of patentability have differing chances of being accepted based not on their optimality, which is difficult to gauge given the opacity of technological projections, but rather based on when new interpretational ideas emerge. Based on contingencies or events one or the other standard may be propelled forward.

Once random events select a particular path the choice may become (relatively) locked in regardless of the advantages of the alternatives. There is no guarantee that the outcome selected from among the many alternatives will be the 'best' one. Therefore, the possibility of increasing returns provides an acute challenge to explanations or justifications of patentability standards described in functionalist or efficiency terms. Specifically, in this paper I claim that sources of increasing returns in the patent system go beyond the law's preoccupation with precedent and legal certainty. ${ }^{10}$

The configuration of complementary institutions in the patent system in which the behaviour of each is affected by the performance of the other, is poorly captured by the legislative and policy framework. The following analysis focuses on specific characteristics of the patent system that make this aspect of social life prone to increasing returns processes. These are inter-institutional linkages, legal authority exercised by prominent institutions and the intrinsic and extrinsic uncertainty associated with patents. A fourth 'source' is not so much a source as a feature of the patent system that intensifies increasing returns, namely the inadequacy of corrective mechanisms (such as litigation) to function as 'efficiency filters'.11 These features of the patent system make the emergence and development of legal doctrine in this field subject to increasing returns.

\section{INCREASING RETURNS: SOURCES AND FEATURES}

Increasing returns (which is contrary to the more conventional notion of diminishing returns), grew out of a study of the social acceptance of technology ${ }^{12}$

interpretations simultaneously held by various stake holders initially. See R. Eisenberg, 'How Can You Patent Genes?, in T. A. Shannon (ed) Genetics: Science, Ethics and Public Policy: A Reader (Lanham, MD: Rowman \& Littlefield Publishers, 2005) 131.

10 Hathaway explores the co-relation between precedent and historical causation as sources of path dependence in the development of the common law. While precedents can doubtless constrain and even prohibit change, it can also provide opportunities and facilitate change. For example, a civil rights group that wants to move from a standard of rational basic scrutiny for gender discrimination to strict scrutiny would bring select issues to court, forcing the court to decide between choices that will incrementally allow them to move towards the desired standard of scrutiny. O.A. Hathaway, 'Path Dependence in the Law: The Course and Pattern of Legal Change in a Common Law System' (2001) 68 Io L Rev 601, 636.

11 Pierson 'Increasing Returns' 260-263.

12 As seen principally in the work of Brian Arthur and Paul David. W.B. Arthur, Increasing Returns and Path Dependence in the Economy (Ann Arbor, Mich.: University of Michigan Press, 1994) [Hereafter Arthur Increasing Returns] and P.A. David, 'Clio and the Economics of Qwerty' (1986) 75 Am Econ Rev 332. Such as in the case of the Qwerty keyboard and VHS format of video recorders. However, the Qwerty example in particular, has been called into question by some analysts as a false example of path 
from whence it was conveyed to economics, economic history and the study of political processes. Increasing returns mechanisms are generated in complex knowledge intense circumstances and according to Arthur many of these are variants of, or derive from four generic sources: First, large set-up or fixed costs creates a high pay-off for further investments in a technology, giving individuals and organisations have a strong incentive to stick with a single option. Secondly, learning effects refer to the knowledge gained in the operation of a complex system that leads to higher returns from continuing use. Thirdly, coordination effects appear when the benefits an individual receives from a particular activity increase as others adopt the same option. Fourthly, adaptive expectation is related to coordination effects, and derives from the self-fulfilling character of certain kinds of expectations. ${ }^{13}$

The above description of the adoption of technology characterises many aspects of social relationships. It takes time and resources to learn new things and we often learn by trial and error. People are more likely to do something that many others are also doing, and may adapt their own behaviour based on what they expect other people to do. North's work is based on an application of these features to institutions. Thus:

in contexts of complex social interdependence, new institutions often entail high fixed or start-up costs, and they involve considerable learning effects, coordination effects and adaptive expectations. Established institutions generate powerful inducements that reinforce their own stability and further development. ${ }^{14}$

It is not just single institutions that generate increasing returns, but institutional arrangements that induce complimentary configurations of institutions and organisations are a powerful source of positive feedback or self-reinforcing feedback. ${ }^{15}$

Pierson builds on Arthur and North's work ${ }^{16}$ to identify four prominent and interconnected features of politics that make this 'realm of social life' conducive to

dependence. See S.J. Leibowitz and S.E. Margolis 'The Fable of the Keys' (1990) 33 J L and Econ 1.

13 Arthur, Increasing Returns, 112-113.

${ }_{14}$ D.C. North, Institutions, Institutional Change and Economic Performance (Cambridge: Cambridge University Press 1990) 95 .

15 Generally see D.C. North, 'A Theory of Institutional Change and the Economic History of the Western World' in Michael Hechter (ed), The Microfoundations of Macrosociology (Philadelphia: Temple University Press, 1983) and P.A. Hall and D. Soskice 'Varieties of Capitalism: The Institutional Foundations of Comparative Advantage' in Varieties of Capitalism: The Institutional Foundations of Comparative Advantage (Oxford: Oxford University Press, 2001) 1.

16 For an elegant summary of key aspects of path dependence and increasing returns see Pierson 'Increasing Returns'; P. Pierson, 'When Effect Becomes Cause: Policy Feedback and Political Change' World Politics 45 (july) 595; P. Pierson, 'The Limits if Institutional Design: Explaining Institutional Origins and Change' (2000) 13 Governance 475; P. Pierson 'Not Just What, but When: Timing and Sequence in Political Processes' (2000) 14 Studies in American Political Development 72. Also see J. Mahoney 'Uses of Path Dependence in Historical Sociology' (2000) 29 Theory and Society 507. 
increasing returns processes. ${ }^{17}$ First, the central role of collective action. In politics the consequences of one's actions are highly dependent upon the actions of others. This is because most of the goods produced in political markets are public goods, most goals pursued by political actors have a 'winner-take-all' quality and there is no linear relationship between effort and effect. Secondly, the bigh density of institutions. The pursuit of public goods requires the construction of formal institutions (such as constitutional arrangements) and public policies that place extensive, legally binding constraints on behaviour. ${ }^{18} \mathrm{New}$ institutions and policies are costly to create and often generate learning effects, coordination effects and adaptive expectations; these by comparison increase the attractiveness of existing institutional and policy arrangements relative to hypothetical alternatives. As social actors make commitments based on existing institutions and policies, the cost of exit from established arrangements generally rises dramatically.

Thirdly, the possibilities for using political authority to enhance asymmetries of power. When certain actors are in a position to impose rules on others, the employment of power may be self-reinforcing as actors use their authority to generate changes in both formal institutions and public policies to enhance their power. ${ }^{19}$ Fourthly, the intrinsic complexity and opacity of politics: It is very hard to measure or observe important aspects of political performance. The complexity and multiplicity of the goals of politics as well as loose and diffuse links between actions and outcomes render politics inherently ambiguous. The prevalence of 'mental maps' ${ }^{20}$ can make understandings of the political world themselves susceptible to path dependence.

Pierson's interconnected features form the closest point of departure to gain analytical specificity by identifying actors and sources of increasing returns specific to the patent system. The sources of increasing returns in the patent system identified here will set up an analyst to correctly identify and explore specific empirical case studies. However, two further aspects of the patent system must be addressed - the first is the relevance of 'timing' in the patent system and the second is the application of the notion of 'inefficient' or 'suboptimal' to patent law doctrine.

\section{The Value of Timing in the Patent System}

One of the key arguments running through this paper is the effect of the complexity of patent law on the content of the decision-making process itself constraining learning processes are to be expected. As Pierson notes, based on cognitive psychology and organisational theory researchers have argued that actors

\footnotetext{
17 Pierson 'Increasing Returns'.

18 Policies are an unorthodox inclusion and although more easily altered than formal institutions, they are nevertheless extremely prominent constraining features of the political environment. They signal rewards and penalties associated with particular activities. ibid, 259

19 P. Bachrach and M. Baratz 'The Two Faces of Power' 56 American Political Science Review 947-52 and S. Lukes Power: A Radical View (London: MacMillan, 1974).

20 Pierson 'Increasing Returns', 260, referring to Arthur Increasing Returns and A. Denzau and D. North 'Shared Mental Models: Ideologies and Institutions' (1994) 47(1) Kyklos 3 in the context of social actors.
} 
who operate in a context of high complexity and opacity are heavily biased in the way they filter information into existing 'mental maps'. 'Confirming information tends to be incorporated and disconfirming information is filtered out.'21. This in turn puts disproportionate importance on early events that may go on to have decisive impact on the substantive content of doctrine not because it is the best or most appropriate standard, but because it came first.

Patent law represents one of the most knowledge-intense aspects of legal interpretation. Novelty, inventive step and industrial applicability or utility, and disclosure requirements tie legal concepts to technical know-how, manifested frequently by the notional person skilled in the art. Often judges attempt to untangle what the person skilled in art, with attributes unique to any particular technology sector, would have understood the inventor's actions or words to mean. When new or immature technologies arise 22 this process can get even more complicated as the meanings and scope of scientific terms take time to settle resulting in doctrinal fluidity. The process creates multiple layers of ambiguity that must be balanced with the need for legal certainty.

It is possible to argue that judges in the highest appellate courts, the supreme court in the US and HL in the UK, are not susceptible to 'mental maps' in this way as their remit specifically extends to considering all relevant information and even changing the status quo if required. However even if this were true, the highest appellate courts in most jurisdictions rarely take up patent law decisions. The evolution of patent doctrine is facilitated by a mixture of patent offices, lower courts, and specialised appellate courts -the Court of Federal Circuit (CAFC) in the US and the European Patent Office (EPO) in Europe that functions as a quasi-judicial authority. ${ }^{23}$ Patent offices in particular function under little oversight sending signals to industry that can quickly build up expectations of value around specific patentability standards. Specialist courts in particular are prone to aggrandisement of their subject matter and pre-formulated 'mental maps' are to be expected here. ${ }^{24}$

\section{INCREASING RETURNS AND SUB-OPTIMAL OUTCOMES IN THE PATENT SYSTEM}

The possibility of inefficient outcomes is a key feature of the unorthodoxy of path dependence ${ }^{25}$ but enjoys different degrees of appeal in economics and politics.

\footnotetext{
21 Pierson 'Increasing Returns' 259.

${ }^{22}$ A term used to represent newly arising technologies. See S. Thambisetty 'Patents as Credence Goods' (2007) 27 Oxford Journal of Legal Studies 707. [Hereafter Thambisetty 'Patents as Credence Goods'].

23 Or as Leith argues notes is an administrative body with judicial function, not necessarily judicial capabilities. P. Leith 'Judicial or Administrative Roles: The Patent Appellate System in the European Context' IPQ 2001, 50. [Hereafter Leith Judicial or Administrative Roles]

${ }^{24}$ According to Landes and Posner this is to be expected at least partly because a specialist court is more likely than a generalist court to identify with the statutory scheme it is charged with administering. W.M. Landes and R.A. Posner 'The Political Economy of Intellectual Property' (2004) AEI-Brookings Joint Centre for Regulatory Studies at http://www.aei.org/docLib/20040608_Landes.pdf accessed 10 October 2008. [Hereafter Landes and Posner The Political Economy of Intellectual Property].

${ }^{25}$ Kenneth Arrow's foreword to Brian Arthur's book gives some indication of the unconventionality of mathematical models used. 'Arthur's papers, while modelled according to the highest analytical standards,
} 
Political actors pursue a range of goals making for a murky environment and consensual outcomes are much harder to come by than in economics, where price acts as the ultimate measuring rod. ${ }^{26}$ The trade-offs in intellectual property law in general, not just in patents, is rooted in the need to induce scarcity in public goods (information) in order to increase the availability of information. The complexity of the goals and complementarities between trade-offs make it difficult or indeed impossible to identify 'inefficiency' or 'sub-optimal' outcomes. Having noted this however, understanding sub-optimal outcomes is necessary in order to empirically evaluate increasing returns sequences.

The very nature of the patent right as monopoly is a carefully crafted anachronism in free markets. The desire to grant incentives for present innovation is matched by the need to facilitate future innovation, a balance that is often struck in infringement actions through a notoriously difficult process. In a process akin to the interpretation of statutes or contracts - meaning of terms used in patents is constructed ${ }^{27}$ on the basis of settled convention in the field, prosecution history and the patentee's own intent. In Europe the construction of patent claims must balance 'fairness to the inventor with certainty for third parties' - a broad guideline that may be interpreted differently in various European jurisdictions based on judicial processes and cultures, at times leading to opposite outcomes in the same set of facts. ${ }^{28}$

Many other questions central to patents can have more than one legitimate and internally consistent answer. For example, the inventive step standard referred to as the 'gate-keeping' criterion attempts to capture the incentive effect of patents by answering this question: 'Would a particular invention have been invented even in the absence of the patent system? If yes, it is an obvious improvement on what existed before, and therefore not patentable. If not, it is inventive and rightfully deserves a patent.' Most jurisdictions apply 'objective' tests often populated with subjective assessments and discretionary standards. ${ }^{29}$ The level of the inventive

sometimes look different from standard economic analysis, and that is a compliment. Expectations are frequently myopic, based on limited information. Prices though always present are not always given the exaggerated importance of much economic orthodoxy, though it must be added that there is an excellent analysis of their strategic use in positive feedback situations. I must emphasise the importance of these vriant approaches, particularly in areas where conventional tools simply fail.' JK Arrow, 'Foreword' in Arthur, Increasing Returns, x. Indeed it is the virtual impossibility of a 'true' inefficiency occurring that is at the heart of Leibowitz and Margolis' scathing attack on path dependence analysts. Leibowitz and Margolis 'Fable of the Keys', n 12 above.

26 Pierson 'Increasing Returns' 260.

27 See for instance the first step of the test laid down in Aerotel Ltd v Telco Holdings Ltd and others, [2007] RPC 7.

28 See for example the divergence in interpretation of 'helical spring' between UK and German courts in Improver v Remington [1989] RPC 69 (CA (Civ Div)), also see Central European Bank v Document Security Systems in [2008] EWCA Civ 19.

29 'The 'windsurfing test' in the UK involves 4 steps based on various standards such as the person skilled in the art, common general knowledge and the content of state of the art, before finally leaving it to the judge to decide whether the invention is nonobvious. Windsurfing International Inc v Tabur Marine (GB) Ltd [1985] RPC 59. Also see KSR v Teleflex US SC 2007 where the US Supreme Court tightened specified that the teaching, suggestion, motivation test of nonobviousness was a cumulative one. 
step standard should be neither too high nor too low - and levels are often technology specific. ${ }^{30}$

In the context of the study of legal processes in the patent system I propose doctrinal incoherence as a sub-optimal outcome. Doctrinal incoherence, as understood and defined here results when there is no legal certainty as to how a particular fact situation will be decided, when legal reasoning can support an assessment either way. This is often the case when there are a number of explicit or implicit interpretational variations to be found in the case law. ${ }^{31}$ Doctrinal incoherence may also result when the law makes technological mistakes when construing the attributes and knowledge of the notional person skilled in the art; it may also result when lateral or neighbouring legal doctrines are affected by the confusion in one particular area of the law. Doctrinal incoherence may be accompanied by abbreviated decision making on the viability or legitimacy of particular legal standards or the reasoning may be overly 'operationalised' without reference to broader questions on the framework or purpose behind the law. This working definition of doctrinal incoherence as a sub-optimal outcome is different to, and must be distinguished from, the discretionary spaces in law that are necessary in order to deal with technology or fact specific circumstances.

One such sub-optimal outcome is presented by the transplantation of the specific, substantial and credible standard (SSCS) of utility from US patent law into European law where it is currently used as a standard of industrial applicability. This standard is not supported by the wording of the European Patent Convention 1973 or 2000 and was adopted with no discussion on its viability or legitimacy via an 'operational' process' 32 whose remarkable success suggests that positive feedback processes are at play. It has been argued that the SSCS as it is applied in Europe has unintended consequences for lateral doctrines such as inventive step and sufficiency of disclosure and creates actual and potential doctrinal incoherence.

\footnotetext{
${ }^{30}$ Recently the UKIPO ran a consultative exercise on the inventive step concluded that on the whole, the right standard was being applied in the UK. However in the context of pharmaceutical drug screening see H. Laddie 'Obvious to Try: What's Invention Got to Do with it?', in D. Vaver and L. Bently (eds) Essays in Intellectual Property law (Cambridge: Cambridge University Press 2005) 91-95.

${ }^{31}$ Such as in the interpretation of the 'exclusion of computer programs as such' (explicit). See Aerotel Ltd, n 27 above.

32 See S. Thambisetty 'Legal Transplants in Patent Law: Why Utility is the New Industrial Applicability' LSE WPS 6/2008, 25 at http://papers.ssrn.com/sol3/papers.cfm?abstract_id=1111966, accessed 10 October 2008. (Jurimetrics: The Journal of Law, Science and Technology Fall (2008) forthcoming) [Hereafter Thambisetty 'Legal Transplants'].
} 


\section{GENERIC SOURCES OF INCREASING RETURNS IN THE PATENT SYSTEM}

\section{INTER-INSTITUTIONAL LINKAGES:}

Inter-institutional linkages as a source of increasing returns arises principally form the insight that not just single institutions but also groups of institutions function as a source of positive feedback. Over-lapping authority, complementarities and the struggle to share responsibility and legitimacy create dynamics that can perpetuate or aggravate initially created advantages or disadvantages. This section details the formal institutional set up of European and US patent systems and the nature of the expansion in roles of some of the actors in order to elaborate on the set up and coordination costs, learning effects and adaptive expectations within inter-institutional linkages in the patent system. Within these processes short-term positional conflicts may be arise while institutions struggle to adjust and adapt to each other's roles and decisions.

Over the last three decades organisations involved in the grant, exploitation and enforcement of patents have emerged from obscurity to play a highly influential role in the political economy; 33 an expansion in role that has brought an inevitable complexity to the institutional structure of the patent system. Patent offices, in particular are no longer confined to basic operations focused on examination functions. Patent offices (including the EPO and the Trilateral office) and courts (general appellate courts, and specialist courts, including the EPO) are usually regarded as key formal elements of the institutional cluster that make up the 'patent system'.

Central research funding bodies should be added to this cluster because of the considerable impact they can have on the post grant exploitation of patents. International bodies such as the WIPO or ARIPO and institutional networks within such bodies are an interesting and significant extension of the patent system; ${ }^{34}$ but for purposes of this paper, the international dimensions are best signified by the extraordinary Trilateral office, comprising the US, European and Japanese patent offices. ${ }^{35}$ This 'Office' is an informal, transgovernmental, regulatory network that often takes a common position in international negotiations.

\footnotetext{
${ }^{33}$ G.B. Doern, Global Change and Intellectual Property Agencies (London: Pinter, 1999) 26.

${ }^{34}$ The emergence of the WIPO group B+ in SPLT negotiations for example. See P. Drahos 'Intellectual Property and Pharmaceutical Markets: A Nodal Governance Approach' (2004) 77 Temple Law Review 401

35 The Trilateral office undertakes a number of activities under 'technical assistance', including the training of patent examiners in countries with newly updated patent offices, as well as the provision of resources such as new computers, links to patent databases and office buildings particularly in South-east Asian countries. See P. Drahos, 'Trust Me: Patent Offices in Developing Countries' CGKD Working Paper, Nov 2007. Also see L. Davies 'Technical Cooperation and the International Coordination of Patentability of Biotechnological Inventions' (2002) 29 Journal of Law and Society Volume 137.
} 
Under the European Patent Convention (EPC) ${ }^{36}$ a single application to the European Patent Office (EPO) results in a patent valid in designated European countries. Each European country also retains its own national patent office where patents are domestically valid and whose procedures are in theory harmonised with the procedures of the EPO. In the case of a patent granted by the EPO, infringement and questions of validity post-grant (and post-opposition if any) fall within the jurisdiction of national courts. Since enforcement and post grant exploitation of patents are left to national bodies and do not directly involve as many institutions as patentability, the problem of inter-institutional linkages and competencies in the European patent system is situated mainly at the level of patentability.

Effectively then, the EPO is not concerned with the manner in which patentability rules impact on infringement. This may lead to divergent validity in different European countries based on differing outcomes in infringement litigation - a possibility described by a leading UK Court of Appeal judge as 'deeply regrettable'. ${ }^{37}$ It can also lead to oddities - for example when EPO rules on patentability directly contradict established rules of infringement. When the EPO decided to accept novelty of purpose patents, it allowed patents on the new use of a substance used in the same way but for a different purpose. Only the intention of the user would indicate which of the two purposes where being deployed. Infringement however takes place irrespective of the intention of the alleged infringer. This has created an as yet unresolved problem. ${ }^{38}$

Additionally the EPC and consequently the EPO, is not formally part of the European Union. Thus the Biotechnology Directive is a EU document that has no direct legal basis under the EPC, although some of the patentability standards were clearly based on EPO practice and Board of appeal decisions. Soon after the Biotech Directive was promulgated, the EPO began using it as a supplement to the interpretation of the EPC. ${ }^{39}$ This apparent symbiosis is not uncontroversial as demonstrated by the failed Directive on computer-implemented inventions initiated by the EC. 40 The provisions of this Directive were little more than the consolidation of some of the most tortuous legal interpretation ever to be developed in patents on computer-implemented invention developed by the EPO - an interpretation that was widely seen to allow patents on computer programs in certain circumstances despite the exclusion of 'computer programs' as such from the EPC. ${ }^{41}$ As noted by the Economics and Social Committee of the EC it would

\footnotetext{
36 EPC 1973, most recently amended in 2000.

37 'Judge Calls for European Patent Litigation' Managing Intellectual Property Mar 20, 2008. However the controversy raised each time outweighs the frequency of the occurrence.

38 'How does one tell whether the person putting the additive into his engine is legitimately using it to inhibit rust or infringing by using it to reduce friction? Merrell Dow Pharmaceuticals Inc v HN Norton and Co Ltd [1996] RPC 76 (HL). Mobil/Friction-reducing additive [1990] OJ EPO 93 and 469.

39 The Directive with some amendments made by the EPO Administrative Council was introduced into the Implementing Regulations of the EPC.

40 European Union, 'Directive on the Patentability of Computer Implemented Inventions' (2002) 2002/0047/COD.

41 Based on the reliance on claim and the fact that 'technical' requirement may be supplied by even the
} 
have been preferable for the EC to take the initiative away from the EPO, which is only competent in one area of intellectual property and was 'naturally attempting to extend its own area of competence and sources of revenue.'42

In the UK in case of divergences between legal standards of the EPO established via examination and Board of Appeal decisions and the Court of appeal, the UKIPO is compelled to follow the Court of Appeal, although it is also mandated to harmonise patentability standards between the UK patents Act and the EPC. ${ }^{43}$ The most sustained of these divergences has developed in the case of computer-implemented inventions. A recent Court of Appeal decision identified at least four different strands of interpretation emanating from the EPO and the UK courts. The situation seems to be intractable with the EPO criticising a recent UK decision as 'against the spirit of the EPC' and the UK High Court adding that 'computer programs are not excluded in all cases. ${ }^{44}$

European patent law continues to explicitly exclude computer programs while adopting interpretations that blow a hole through it. The density of institutions involved diffuses responsibility and the convoluted legal positions arguably, fall just short of outright contradictions. The dynamic is resonant of learning, coordination and adaptive effects within groups of institutions, where continued use of a poor legal standard has led over time, to returns from continued use. The juxtaposition and overlap of competencies and the confounding of legislative and interpretive function is a running theme in the European patent system that makes early institutional or legal initiatives inordinately important - institutions can be expected to adapt making it more difficult to exit specific policies.

The US patent system presents a not dissimilar situation although the direct institutional complexity of the European system is avoided. US legal doctrine is dominated by the Court of Appeal of the Federal Circuit (CAFC) a specialist court that occupies a unique role as an appellate body, jurisdictionally demarcated by subject matter rather than by geography. The basic premise behind establishing the CAFC distinct from the 12 regional circuits, was the belief that centralisation of authority would lead to clearer, more predictable patent law. However studies have suggested that the mere establishment of a specialist court has not lead to consistency and predictability of outcome. ${ }^{45}$

The creation of the CAFC seems to have had a positive impact on the number of patent applications, number of patents issued and the success rate of patent applications, the amount of patent litigation; 46 but all of these have not

most banal aspects of computer-implemented inventions such as servers and general-purpose computers. 42 ESC Opinion, COM (2002) 92 Final - 2002/0047 (COD) (19 September 2002) 5.4.

43 See for example the discussion of the Patent Examiner in Optimumportfolio.com LLC [2004] BL $\mathrm{O} / 215 / 04$

${ }_{44}$ Astron Clinica Ltd and Others [2008] EWHC 85 (Pat).

45 See R.P. Wagner and L. Petherbridge 'Is the Federal Circuit Succeeding? An Empirical Assessment of Judicial Performance' (2004) 152 U of Penn L Rev 1105.

46 W.M. Landes and R.A. Posner, The Economic Structure of Intellectual Property Law (Cambridge, Mass: Harvard University Press, 2003) Ch 12; see also Landes and Posner, The Political Economy of Intellectual Property 26-27. Also see J.L. Turner, 'In Defence of the Patent Friendly Court Hypothesis: Theory and Evidence' (2005) <http://ssrn.com/abstract=713601> accessed 10 October 2008. (linking an upsurge in 
necessarily had a positive effect on technological progress. While interest group politics seem to have led to the creation of the court; its 'mission' orientation and specialised character must be regarded as an informal institution that impacts on the direction and content of legal doctrine. Studies have predicted and identified, a 'pro-patent' attitude that favours more and stronger patent rights. According to Landes and Posner, this is to be expected

simply because a court that is focused on a particular government program, like an administrative agency (invariably specialised), is more likely than a generalist court to identify with the statutory scheme that it is charged with administering. ${ }^{47}$

Higher appellate courts that are generalist in nature have recourse to a greater variety of approaches to a legal problem. They are more likely to adopt a 'purposive' approach to interpretation where the appropriateness of a prohibition on exclusion from patentability is explored, and may identify issues that are better dealt with by legislatures. In contrast, specialist courts often take the 'purpose' of a statute as given and proceed to address questions of interpretation at least partly as an exercise in semantics. ${ }^{48}$ An example exemplifying the contrast can be seen in the case of the patentability of the genetically modified onco-mouse at the European Patent Office, a body with specialist quasi judicial functions and the Canadian SC, a generalist appellate body. 49

In contrast the status of the EPO is a curious one. It is a specialised administrative body with quasi-judicial functions, and a corporate structure geared to service consumers. These consumers are often actual or potential patent holders, and only infrequently are they public domain stake-holders. In this context, it is to be expected that the EPO will function with a pro-patent attitude we can expect within specialist courts. This in itself is not surprising, but what is

patenting in the US to the so-called 'Patent Friendly Court Hypothesis'); M.D. Henry and J.L. Turner, 'The Court of Appeals for the Federal Circuit's Impact on Patent Litigation' (2006) 35 J Leg Stud 85.

47 W.M. Landes and R.A. Posner, 'An Empirical Analysis of the Patent Court' (2004) 71 U Chi L Rev 111,112 .

${ }^{48}$ For a full analysis see S. Thambisetty 'The Institutional Nature of the Patent System and its Impact on Bioethical Decision-Making' in Lenk et al (eds), Ethics and law of Intellectual property: Current Problems in Politics, Science and Technology (London: Ashgate, 2007) 247-267 [Herafter Thambisetty 'Institutional Nature of the Patent System'].

49 ibid. Other peculiarities that impact on the quality and content of the intellectual debate on patentability include the low number of judges that decide such cases. Wagner notes that in the US, Judge Lourie authors most of the cases identified by commentators as relevant to biotechnological inventions. In the UK too the association of patent matters with a limited number of senior judges at the Court of Appeals is significant as the House of Lords hears relatively few patent cases. In the context of a specialist court's mandate, Wagner and Petherbridge recommend 'evangelism' and 'enforcement' activities by individual judges through dissenting opinions, internal discussions or clearer statements on methodology. This, according to the authors would establish a normative construct that is likely to improve the court's performance with regard to its overall mandate. See Wagner and Petherbridge, n 45 above. Also see S. Rizzello and M. Turvani, 'Institutions Meet Mind: Way out of a Deadlock' (2002) 2(2) Constitutional Political Economy 165. 
remarkable is the apparent complacency with which the conflicting institutional roles Patent Offices are set up to play is received.

To illustrate, there is an existing rule that allows infringement actions to be brought to the Comptroller of the Patent office if the alleged infringer agrees. In 2002 the Department of Trade and Industry together with the UK patent office proposed to relax the rules allowing for infringement action even without the alleged infringer's permission - a proposal described as the 'least thought through, most ill considered proposal to emerge for many years'.50 There is a conflict of interest in allowing the same entity that grants patents to sit in on the legally valid scope of the patent, but it indicates an unwarranted trust in the role of the patent office. The allocation of responsibility and trust may be due in part at least to the present context of a knowledge-intense or technically opaque areas and the de jure and de facto role epistemic communities ${ }^{51}$ such as patent offices play here.

The above proposal may have been driven in part by a perception that UK patent litigation is excessively costly because of the number of procedural tools such as disclosure, experiments and cross-examination. In 2003 the UK Patents Court introduced a new streamlined court procedure geared towards a one-day trial six months after the order for such a procedure is given. It eliminates a number of steps within standard trial directions that fail a cost-benefit analysis and was set up amidst concern that patent litigation would drift towards more 'efficient' courts such as in Germany. The rapid procedure could become an important strategic tool in multi-jurisdictional patent litigation ${ }^{52}$ as an early judgement in the UK may be used persuasively in other European jurisdictions, increasing the profiles of UK judges, and generating coordination effects.

The European Patent Litigation Agreement is a proposal to set up a Europewide litigation agreement as a solution the current fragmented framework. A number of EU countries promote a rival proposal to litigate patents under the ECJ, a European Union judicial body that would give initiative in the important aspect of the single market back to the EU rather than to the EPO that administers the EPC. ${ }^{53}$ Organisational persistence here is remarkable and its causes (including the resource implications of re-designing institutions) and consequences are worth exploring further. ${ }^{54}$

\footnotetext{
50 'Judge Slams Patent Court Proposal' Managing Intellectual Property, March 02, 2003.

51 A network of knowledge-based experts or groups with an authoritative claim to policy-relevant knowledge within the domain of their expertise. Members hold a common set of causal beliefs and share notions of validity based on internally defined criteria for evaluation, common policy projects, and shared normative commitments. Peter M Haas, 'Introduction: Epistemic Communities and International Policy Coordination' (1992) 46 IO 1.

52 J. Hitchcock, 'A Case for Streamlined Procedure' (2005) Mills and Reeve < http://www.cambridgenetwork.co.uk/POOLED/ARTICLES/BF_NEWSART/VIEW.ASP?Q=BF_ NEWSART 138393> accessed 10 October 2008.

53 'European Patent Litigation Push Stumbles' available here http://www.managingip.com/ Article.aspx?ArticleID=1393903 accessed 10 October 2008 and 'Judge calls for European Patent Litigation System' available here <http://www.managingip.com/Article.aspx?ArticleID=1895148\&LS= EMS169576>, accessed 10 October 2008 .

54 The major hurdles to moving forward with the proposal for the new Europe -wide patents court includes the problem of language, the question of bifurcation of validity and infringement, judicial
} 
The European system in particular seems tied to an institutional design that relies on collective action between the EPO, national patent offices and national courts in over 20 countries to bring about a harmonised working system. Collective action in particular includes many of the features conducive to positive feedback, 55 because institutions within the system have adaptive expectations and constantly adjust behaviour with respect to how other institutions may act.

Examination procedures are the key to substantive patentability standards. What can or cannot be patented is a signal that is sent out initially from the patent office; and can build up expectations in capital markets that can be hard to reverse even for courts. Courts are often keen to coordinate with patent offices in establishing examination methodologies that are conducive to predictability and consistency. The Trilateral Office is a framework for coordination that ostensibly 'collaborates' on examination procedures at each of the patent offices namely Japanese, European and US in a bid to reduce legal uncertainty for trans-national corporations looking for intellectual property protection in multiple jurisdictions. Even within developed countries, explicit harmonisation of substantive standards raises a number of ideological issues - within this context the work of the Trilateral office has the outward marking of an 'epistemic community' and coordinates patentability standards on such controversial issues such as biotechnological inventions, business methods and computer-implemented inventions. The Office negotiates as a single body at WIPO negotiations on the SPLT - the Substantive Patent Law Treaty and is an explicit competitor for regulative and normative decision-making space.

The Trilateral Office is essentially a closed community of regulators that raises important questions of accountability ${ }^{56}$ and perpetuates the view that international coordination and harmonization of patent law is a technical debate to be resolved solely by technical cooperation. This collective dynamic has the potential to generate learning and coordination effects in the emergence and evolution of patentability standards.

\section{Legal Role and Authority of Patents Offices and the Force of 'EXPANSION':}

Asymmetry in power as a source of increasing returns is based on the reasoning that powerful entities will work at increasing their own power, generating selfreinforcing processes. Patent law emerges from three distinct but related spheres

procedure to be followed, the cost of setting up the court and location. See Draft Report on the Impact of the Patents Court in UK (UKIPO October 2008, draft in progress). The author is an academic expert on this commissioned study.

55 G. Marwell and P. Oliver, The Critical Mass in Collective Action: A Micro-Social Theory (Cambridge: Cambidge University Press, 1993). Pierson sees Collective action in politics as a source of generic returns distinct from the density of institutions. Pierson Increasing Returns, 258.

56 L. Davies, 'Technical Cooperation and the International Coordination of Patentability of Biotechnological Inventions' (2002) 29 Journal of Law and Society 137. But also see M. L. Cheek 'The Limits of Informal Regulatory Cooperation in International Affairs: A Review of the Global Intellectual Property Regime (2001) 33 George Washington International Law Review 277. 
of authority - judicial, legislative and examination by the patent office. Judicial and legislative authority is capable of being scrutinised in well-defined ways; by contrast the patent office as an institution is subject to little oversight and works to poor principles of accountability. In addition expanded roles of patent offices in UK, US and European jurisdictions have exacerbated power asymmetries between those who advocate more property rights and those who would like to constrain this expansion using fast receding normative boundaries.

The legally backed authority of the patent office is first and foremost a formal constitutive 'examination function' that it fulfils under patent statutes. The technical function uses scientific-legal terminology that makes it a closed book even to non-patent intellectual property lawyers. Most importantly the examining function is supposed to occupy a different space from legislative interpretation carried out by judicial bodies. In effect however patent office often function like courts, exercising quasi judicial roles - a juxtaposition of roles that is troubling given the apparent sanctity it gives decisions of an administrative body.

Courts work with established rules of legal interpretation and actively justify and reason outcomes - a characteristic of the judicial process that enables methodological and substantive scrutiny. The patent office is an administrative agency whose internal structure and processes are difficult to scrutinise. European patent office 'judges' in contrast are produced by a system directed towards one goal - 'examining patents' a function based overwhelmingly on documentary evidence. ${ }^{57}$ Procedural expertise such as 'evidence sifting' or weighting of arguments that may be routinely expected from judges of national courts are not common this context.

Examining guidelines derive content from litigated rules and doctrines, but also impact on legal doctrine directly and indirectly, in a feedback loop. One of the most dynamic interpretive tools in patent law is the 'person skilled in the art'. This notional person has the aptitude, knowledge and know-how of an average person of skill in any particular art and provides a technology-specific link to the internal cognitive processes of individual researchers in scientific and technical development. ${ }^{58}$ Broad questions such as inventive step or sufficiency of disclosure with direct impact on the social value of innovation boil down to what the person skilled in the art knows or does. Since patent offices have considerable say in specifying how much the person skilled in the art can be assumed to know through examination procedures, they set key doctrinal standards. Substantive patent law doctrine is routinely broken down to similar incremental 'operational' measures that are often fully controlled by patent offices. Due to the selfreinforcing nature of the patent system, an 'operational' measure once set up can be very difficult to modify or overrule. Swiss medical claims are an oddity that illustrates the operationalisation of substantive patent law.

57 For a full discussion of this and other points see Leith Judicial or Administrative Roles.

58 R. Eisenberg, 'Obvious to Whom? Evaluating Inventions from the Perspective of PHOSITA' (2004)

19 Berkeley Tech. L.J. 885. 
Prior to EPC 2000, European and therefore UK patent law excluded methods of medical treatment on grounds of it being incapable of industrial applicability. ${ }^{59}$ The reasoning behind this is the idea that some fields of endeavour should not be subject to commercial or industrial interests. However the EPC allows for the patenting of the first medical use of substances that are already known. Additionally, as a response to pressure from the pharmaceutical industry the EPO was interested in extending patent product protection to second medical use of known products. Second medical uses of known chemical entities are often commercially significant because expensive safety or toxicology profiling for the substances or compositions already exist.

The second medical use of a known substance is a 'method' of medical treatment and falls foul of the exclusion on grounds of lack of industrial applicability. Swiss medical use claims, so called as it was first designed by the Swiss patent office gets over this hurdle by allowing claims in the form 'Use of X to manufacture medicament Y'. In G05/83 EISAI/Second Medical Indication the EPO disallowed a claim in the form -

'The use of a (certain substance or composition) for the treatment of the human or animal body by therapy'

Because it is the same as

'A method of treatment of the human or animal body by therapy with a (certain substance or composition)'

Which falls foul of Art 52(4). However they allowed:

'The use of a (certain substance or composition) for the manufacture of a medicament for a specified new and inventive therapeutic application'

Note here that the process of manufacture itself in all three cases do not differ from the known processes for the same substance or composition. There is no difference in the substance of what is protected under all three of these claims, however only the third one ostensibly fulfils competing legislative requirements while extending pharmaceutical protection to second and subsequent medical uses of substance. Such claims known as 'manufacturing use' claims are therefore new only in terms of the new therapeutic use of a known chemical entity.

The combination of technical language and operationalisation of patent law; and the fact that patent offices are the first agency to engage with new technologies, makes them powerful agenda-setters. A recent example of 'agendasetting' with implications for European Patent law is provided by the treatment of

59 Art 52(4) EPC 1973, Art 53 (c) EPC 2000. Also see UKIPO, 'Examination Guidelines for Patent Applications Relating to Medical Inventions in the UK Patent Office' (2004) <http://www.patent.gov.uk/patent/reference/mediguidlines/index.htm> accessed 10 October 2008. 
the 'technological arts' test at the US Patent Office and the BPAI. ${ }^{60}$ Carl Lundgren's application for a method of calculation was initially found unpatentable by the USPTO as being 'outside the technological arts, ... without the disclosure, or suggestion of a computer, automated means or apparatus of any kind'. ${ }^{61}$ On appeal however, the rejection was reversed on a divided opinion at the BPAI which found no basis for the 'technological arts' test, specifically rejecting judicial precedent stating that there could be no 'technological arts' test separate from the enumerated classes in $\int 101.62$ The move recasts substantive changes in 'operational' terms - in this case as a matter of removal of one of the steps in the examining procedure. ${ }^{63}$

As is amply clear from the European context, reliance on 'technology' or 'technical aspect' is not without problems since mere association with banal computer equipment should not make otherwise unpatentable subject matter patentable. However removing the 'technological arts' test from the USPTO's examining process is a radical signal that it intends to steer away from the limiting notion of 'technology'. The USPTO often presents itself as a global agenda-setter in undermining the 'technical' aspect of patent eligibility. Specifically the interim guidelines put in place after the Lundgren decision strengthen the negotiating position of the US in international fora such as the WIPO and aid the case for going beyond the TRIPS Agreement's limiting use of the term 'technology':

The United States is a leader in the protection of intellectual property and strongly supports patent protection for all subject matter regardless of whether there is a 'technical aspect' or the invention is in the 'technological arts'. The application of a 'technological art' requirement could be used to preclude the patenting of certain inventions, not only in the United States but also in other jurisdictions. ${ }^{64}$

Admittedly, an agenda-setting power in itself may not be problematic for a knowledge-intense field such as patent law where the cognitive dimensions of institutions can be expected to play out and 'mental maps' are bound to develop. However, the agenda-setting power often comes coupled with an explicit programme of extension of the reach of intellectual property - again behaviour that is not surprising for a specialist agency, but one that may contradicts conditions conducive to capturing the social value of innovation.

\footnotetext{
60 Exp Lundgren 76 USPQ 2d 1385, 1386 (Bd Pat App \& Inter 2005).

61 Exp Lundgren 76 USPQ 2d 1385, 1386 (Bd Pat App \& Inter 2005).

62 In re Musgrave 167 USPQ 280 (CCPA 1970) and Toma 197 USPQ 857 (1978).

63 See discussion in S. Thambisetty 'Legal Transplants'. The decision develops the USPTO's position on business method and software patents post State Street Bank and Trust v Signature Financial Group $149 \mathrm{~F} 3 \mathrm{~d}$ 1368 (Fed Cir 1998) where it was held that there was no patentability exception for 'methods of doing business'. However, in its decision in ExP Bilski the BPAI noted that Lundgren should not be read as eliminating the 'technology' requirement for patents. Exp Bilski (Bd Pat App \& Inter 2006).

64 USPTO, Interim Guidelines for the Examination of Patent Applications for Patent Subject Matter Eligibility (22 November 2005) 45, see also 42-43.
} 
Related to the cognitive dimension of inter-institutional interactions, are specific policy paradigms administered by powerful institutions that which function as an explicit source of increasing returns. Policies grounded in law are prone to increasing returns as they establish many of the rewards and penalties associated with particular activities and are a strong reinforcing feature of existing institutional arrangements. ${ }^{65}$ Rather than relegate policy ideas to the back of theoretical constructions, ${ }^{66}$ it is important to recognise that the force of ideas is an independent variable in the patent system that must be understood in the context of specific institutions. Patent offices are able to set policy and legal arrangements in a way that constantly strengthens intellectual property rights in ways that are often not warranted or justified by original legislative mandates.

An example of a 'policy paradigm'67 or 'directional idea' that has emerged recently in intellectual property law in general and patent law in particular is 'expansion' - expansion in types of subject matter that can be protected by intellectual property and the expansion in scope and strength of such rights. The US and the European patent system are both subject to this paradigm; even in jurisdictions averse to 'expansion', law and policy may be tailored as an opposition to this idea, emphasising its force. This aspect transforms a plausible balance in the power and responsibility of the patent office to one where ideological manipulation increases power asymmetries. Key to understanding this is to consider some of the ways in which the roles and function of this body has changed in recent times.

A recent decision of the EPO is widely regarded as having made it easier to get patents on diagnostic methods despite the explicit exclusion of this category of inventions from patentability in Art 52(4) of the EPC. ${ }^{68}$ The EPO inter alia justifies restricting the meaning of this exclusion only to a small number of methods where every aspect is directly practised on a human or animal body, on the grounds of art 4(3) of the EPC. This article is an introductory provision that states that it is the task of the EPO to grant patents; a provision that must be read in the context of the rest of the Convention. However according to the EPO, any exceptions to this mandate such as those in art 52(4) are therefore to be construed narrowly. ${ }^{69}$ This is a 'political' reading of art 4(3) that furthers the legal and political agenda-setting power of the EPO.

The pressures of revenue-raising can also lead to situations where the social benefits of intellectual property are constricted in favour of the expanding the reach of patent offices. Formally, in most countries patent offices are 'statutory persons', a constitutive rule that seeks to maintain the integrity of the office. Since

${ }^{65}$ Pierson 'Increasing Returns'.

${ }^{66}$ Historical institutionalism is most receptive to the study of ideational processes. See D. Beland, 'Ideas and Social Policy: An Institutionalism Perspective' (2005) 39 Social Policy and Administration 1 (in the context of the welfare state). The author points out that empirical studies may and do engage with ideas to some extent when they discuss agenda-setting processes, but theoretical discussion about policy ideas is also often lacking in the historical institutionalist literature.

${ }^{67}$ Defined by Beland as the 'structured intellectual background of policy decisions'. ibid.

68 Diagnostic Methods G 0001/04 OJ EPO (2006) 334.

69 ibid 342. 
the late 1980s and 1990s, patent offices' status has been changed in a number of countries, bringing with it greater powers over its finances, personnel and other operations. A number of patent offices are now self-funded including that of the UK and the US. 70

Patent renewal fee structures are an integral part of patent offices as revenue generators. In an environment where it is not possible to analyse whether the value of an innovation justifies the $\mathrm{R} \& \mathrm{D}$ costs, increasing patent renewal fees leads to reduced length for inventions of lesser social value. ${ }^{71}$ However selffunded patent offices can distort fee structures when maximisation of revenue conflict with the imperative to optimise the social value of innovation. Gans et al. predict that a financially constrained, self-funded patent office can be expected in course of time to reduce renewal fees and increase initial application fees in a bid to increase revenue. Reducing renewal fees increases the inventor's expectation of profits that can then be appropriated through initial high application fees. Over a period of time it can distort social welfare by discouraging the filing of some useful patents while encouraging the effective life of others. ${ }^{72}$

Explicit policy-making roles and opportunities have recently been added on to patent office functions. For example, the USPTO Corporate Plan undertakes to 'help protect, promote and expand (emphasis added) intellectual property rights systems throughout the United States and abroad'.73 When patent offices avow the expansion of intellectual property rights, they function as an interest group that drives up the demand for greater and stronger intellectual property rights. This self-reinforcement is further intensified because of inherent asymmetry between the value that creators of intellectual property place on having property rights and the value that would be users place on the freedom to use without obtaining a license from the patent holder. It is easier to organise interest groups demanding an expansion of intellectual property rights than it is to get would be users to oppose such an expansion. Landes and Posner offer the absence of serious opposition to the bill that became the Sony Bono Copyright Term Extension Act of 1998 in the US as evidence of this persistent asymmetry. ${ }^{74}$

The UKIPO has recently launched a programme to promote the value of intellectual property among school children enrolling Wallace and Gromit to capture the imagination of young children. ${ }^{75}$ The material includes measures to

\footnotetext{
${ }^{70}$ Lemley argues that converting patent office into a nimble customer-oriented body is an indefensible position for a quasi-judicial administrative agency entrusted with issuing patents in the public interest. M. Lemley, 'Rational Ignorance at the Patent Office' (2001) 95 Nw U L Rev 1495.

71 S. Scotchmer, 'On the Optimality of the Patent Renewal System' (1999) 30 RAND J Econ 181. Also see F. Cornelli and M. Schankerman, 'Patent Renewals and R \& D Incentive' (1999) 30 RAND J Econ 197.

72 J. Gans et al, 'Patent Renewal Fees and Self Funding Patent Offices' (2004) 4 Topics in Theoretical Economics; Legal Studies Research Paper no 64, Faculty of Law, University of Melbourne, 9 and 14 $<$ http://ssrn.com/abstract $=515162>$ accessed 10 October 2008.

73 US Patent and Trademark Office, 2000 Corporate Plan, 17; US Patent and Trademark Office, 2001 Corporate Plan, 71.

74 Landes and Posner The Political Economy of Intellectual Property.

75 'Cracking Ideas' uses 'lesson plans, a nationaiwde competition, teaching resources and a dedicated website to bring innovation into lessons for Key Stage Two as part of the national Curriculum'
} 
tackle 'IP crime', an ideologically contested notion. In the UK the Gower Review of Intellectual Property recommended measures to help the patent office take a strategic view of IP. This involved setting up of the Strategic Advisory Board for Intellectual Property (SABIP) as an advisory body to the government with a broad mandate to commission external research. ${ }^{76}$ Although there is direct exhortation to involve all stakeholders, it remains funded by the patent office. All of the above measures expand the power and reach of patent offices by increasing the visibility and seeming indispensability of intellectual property rights, and by further entrenching the patent offices as epistemic communities. Informal policies, such as the idea of 'expansion' of intellectual property together with more formal institutions that back up the legal authority of patent offices, are a key source of self-reinforcing behaviour that impacts on the emergence and development of legal doctrine.

\section{INCREMENTALISM AND UNCERTAINTY ASSOCIATED WITH PATENTS:}

A direct consequence of the imprecise nature of patents as property rights, inherent opacity of value and resulting uncertainty is the incremental nature of doctrinal development here. Given the risks of formulating law under new circumstances, learning behaviour and adaptive expectations are prominent in the patent system. Satisficing and incremental changes to legal doctrine are the norm. Reform takes place in small, operational chunks and reasoning is often by analogy rather than through the mooting of radical ideas. Furthermore, there is no central organizing principle (such as price in economic markets) to evaluate performance in the patent system, except perhaps for 'legal certainty' which functions as a status quo bias. Herein lies the possibility that incrementalism could lead through a series of sequences that are difficult to reverse, to path dependence in the patent system. Radical ideas that might reverse direction are difficult to formulate given the reasoning process which is inherently skewed in favour of past sequences.

The opacity of patents as property rights, leading to considerable uncertainty ${ }^{77}$ is one of the key reasons why incremental changes are more likely than radical ones. Patents carry considerable intrinsic and extrinsic opacity. Extrinsic uncertainty in patents is a result of an attribute of knowledge that makes it 'lumpy'. ${ }^{78}$ Some patents are very valuable while some are worth almost nothing - this makes firm patent totals a very noisy indicator of the underlying economic value of the innovations. ${ }^{79}$

\footnotetext{
$<$ http://www.ipo.gov.uk/press/press-release/press-release-2007/press-release-20070426.htm>accessed 10 October 2008.

76 Gower Review, Recommendation 46 and 47. The role of this non-departmental public body includes responsibility for strategic oversight of IP policy; challenging government policy-making; and advising on how the UK's interests should be pursued in international IP negotiations.

77 See J. Bessen and M. Meurer, Patent Failure: How Judges, Bureaucrats and Lanyers Put Innovators at Risk (Princeton N.J.: Princeton University Press, 2008) and M. Lemley and C. Shapiro 'Probabilistic Patents' (2005) 19 Journal of Economic Perspectives 75. Also see S. Thambisetty 'Patents as Credence Goods'.

78 C. Long, 'Patent Signals' (2002) 69 University of Chicago Law Review 625.

79 B.H. Hall, A. Jaffe and M. Trajtenberg, 'Market Value and Patent Citations: A First look' (2001)
} 
The principal problem that makes the intrinsic uncertainty qualitatively different from extrinsic uncertainty is the persistent inability to quantify the effect of novelty, inventive step, disclosure and breadth on a patent's economic value. Unsettled legal doctrine and scientific terminology ${ }^{80}$ can also lead to ambiguity in property parameters. The literature centres on aspects such as the number of times a patent is cited, the length of its renewal, or the number of countries where it is taken as proxies for its intrinsic value. Often, patent lawyers may rely on their own judgment or experience to gauge or 'get a feel for' the overall quality of a patent based on various clues revealed by the patent and its file history. (In fact, all methods of patent valuation involve some element of forecasting and speculation). This can be seen for example in the patent renewal process where even owners who make quick, unreasoned judgments make implicit valuation decisions in addition to more explicit valuations necessary when considering licensing, litigation or sale.

To give two examples of incremental change, when biotechnology brought the prospect of gene sequence patentability most patent offices responded as though gene sequences were variations of chemical products of which most patent offices had considerable experience by the early 1990s. This turn of events is credited with a number of oddities in the way in which genes are now treated in the patent system including the reliance on structural elements rather than the 'information' nature of gene sequences. ${ }^{81}$ Similarly with the first cases of genetically modified animals, the EPO was inclined to grant expansive protection - a legal position developed from the fact that plant varieties had their own form of intellectual property rights, whereas inventors of 'animals' could only rely on the patent system. This was used to justify patentability in spite of the exclusion of animal and plant varieties. ${ }^{82}$

Patent law is often interpreted in a 'technologically-specific' way (in spite of a monolithic legislative framework) in both European and US law. Illustratively in both the US and at the EPO, high-level functional descriptions are sufficient to disclose a computer-implemented invention - disclosure of source or object code, flow charts or detailed descriptions of the patent programme are not required. By contrast, gene sequences have to be fully described even where such level of detail is unnecessary given what the notional person skilled in the field knows. ${ }^{83}$

University, NBER Working paper no 7741, National Bureau of Economic Research at http://www.card.iastate.edu/research/stp/papers/hall-jaffe-trajtenberg.pdf, accessed 10 October 2008. This point was first made by Scherer in 1965 and developed later by him and his co-authors. F.M. Scherer, 'Firm Size, Market Structure, Opportunity and the Output of Patented Inventions' (1965) 55 Am Econ Rev 1097; D. Harhoff, F.M. Scherer and K. Vopel, 'Exploring the Trail of Patent Value Distribution' in Ove Granstrand (ed), Economics, Law and Intellectual Property: Seeking Strategies for Research and Teaching in a Developing Field (Boston, Mass: Kluwer, 2003) 279.

80 Specifically see discussion of Kirin Amgen Inc v Hoechst Marion Roussel Ltd and Transkaryotic Therapies (No 2) [2004] UKHL 46 [59] in Thambisetty, 'Patents as Credence Goods'. In this case the interpretation of 'host' cell was key to the invalidation of one of the most lucrative biotechnology patents.

81 R.S. Eisenberg, 'How Can You Patent Genes?' (2002) 2 The American Journal of Bioethics 3.

82 See O. Mills, Biotechnological Inventions: Moral Restraints and Patent Law (Burlington, Vt.: Ashgate Publications, 2005) 61-75.

83 D.L. Burk and M.A. Lemley 'Is Patent Law Technology-Specific' (2002) 17 Berkeley Tech LJ 1155. 
Technological specificity originates in the patent office in examination guidelines, although patent offices have no recourse to the judgement of contemporaneously active technological practitioners. ${ }^{84}$ Patent offices can also be expected to mimic the practice of other offices in comparable jurisdictions. Such 'borrowing' is an inevitable consequence of risk-averse patent examiners, who abandon a resourceintense root and branch investigation of new legal standards in favour of an 'itwill-do' solution. Once established basic understandings or orientations can become tenacious, ${ }^{85}$ and the exit option far too costly.

Interpretation of patent law in technologically specific ways also reinforces the agenda-setting power of the patent office and enables the operationalisation of substantive standards, leading to the possibility of what one commentator terms 'the whitewashing of the formal criteria of eligibility in order to secure the patenting of potentially ineligible and otherwise unpatentable subject matter.' 86 Conversely, incrementalism in the patent system may also create rare opportunities for reform in favour of interests currently not well represented in the patent system if weaker parties can foresee the effects of incremental changes to legal standards better than more powerful institutions, or the external political situation changes creating coalitions of weaker parties that may be able to push for reform. ${ }^{87}$ In a point related to the need for external stimulus for reform, if the pattern of change is largely 'operational' and 'incremental' there is very little scope for alternate conceptual frameworks to take seed and gain ground except in exceptional and revolutionary terms. Incrementalism in the patent system may thus also have the significant result of limiting the effect of 'framing' as a form of public dialogue in 'which actors wishing to change political processes offer an alternative conceptual scheme through which to interpret those political processes.' 88

84 R.S. Eisenberg 'Obvious to Whom? Evaluating Inventions from the Perspective of PHOSITA' Berkeley Tech. L.J. (2004) 19885.

85 Pierson 'Increasing Returns', 260.

${ }^{86}$ J. Pila, 'Bound Futures: Patent Law and Modern Biotechnology' (2003) 9 B U J Sci and Tech L 326, 350. The author however argues that non-threshold requirements continue to give effect to threshold criterion - a weakened claim in the context of increasing returns processes. For example, technologyspecific rules of interpretation in the UK and Europe for computer-programs have led incrementally to a weakened subject-matter eligibility enquiry.

${ }^{87}$ Further exploration of this possibility is called for. An useful analogy can be drawn with the role of the NAACP in the US in the mid 1960s and its efforts to 'make' civil liberties laws by incrementally litigating against segregation. M. Tushnet Making Civil Rights Law: Thurgood Marshall and the Supreme Court, 1936-1961 (Oxford: Oxford University Press, 1994). Also see Hathaway, 'Path Dependence in the Law', 643.

88 P. Drahos, 'Does Dialogue Make a Difference? Structural Change and the Limits of Framing' (2008) 117 Yale L. J. Pocket Part 268. Drahos's arguments are a response to Amy Kapczynski's challenge to structural explanations of regulatory globalisation. She proposes that framing theory is more persuasive than public choice theory. A. Kaczynski 'The Access to Knowledge Mobilisation and the New Politics of Intellectual Property' (2008) 117 Yale L. J. Pocket Part 804. 


\section{The Skewed Nature of Patent Litigation:}

The fourth source of increasing returns is an aspect of the patent system that intensifies positive feedback. Conventionally, the 'evolution to efficiency' paradigm seems to describe a linear process where

(common) law evolves towards efficient rules because, inter alia, judges favour efficient rules, inefficient rules are litigated more often than efficient ones, litigants advocating efficient rules have greater incentives than those advocating inefficient rules to incur legal expenses that increase the likelihood of a favourable decision, and resorting to court settlement is more likely in cases in which legal rules governing the dispute are inefficient. ${ }^{89}$

The above view of litigation as 'efficiency facilitator' is not supported empirically in the patent system. The economics of patents often create a grave imbalance of incentives between a patentee and a potential challenger to the validity of the patent with obvious repercussions not just for patent enforceability but also for the creation and continuance of appropriate doctrine. The rules and processes that survive and get entrenched are often the ones that survive the system of litigation itself, with its imperfect selection process.

The cost of litigation varies dramatically with the amount of money at stake. The fact that participants in high-stakes cases choose to spend more strongly indicates that by spending more a party can increase its chances of winning. Farrell and Merges' study cites money and skewed incentives as the main reason why patent litigation is unable to weed out inefficiency. ${ }^{90}$ Patent litigation is different from a purely private dispute over a sum of money where the stakes are alike for both parties for a patentee's incentive to defend his patent grossly exceeds an alleged infringer's incentive to challenge it. The asymmetry of stakes results from the following endemic aspects.

First, in the case of multiple infringers patent invalidity judgments result in patents being turned into public goods. A patent attacker does not have the ability to exclude others from appropriating the benefits of a successful attack. ${ }^{91}$ Secondly, there is the 'pass through problem'. When multiple infringers compete in a product market royalties are often passed through, at least in part, to consumers downstream. Therefore there is no economic reason to expect direct infringers to have appropriate incentives to challenge a patent even if they act collectively. Thirdly, the incentive to challenge in the first place can be quite skewed. Losing a challenge can be a very different outcome from uncomplainingly

89 O.A. Hathaway, 'Path Dependence in the Law', 636.

90 J. Farrell and R. Merges, 'Incentives to Challenge and Defend Patents: Why Litigation will not Reliably Fix Patent Office Errors and Why Administrative Patent Review Might Help' (2004) 19 Berkeley Tech LJ

${ }^{91}$ As per Farrell and Merges: 'If there are five infringers of equal size, each gets only a fifth of the gains from a successful challenge because each is only paying a fifth of the patentee's total rovalties. Therefore the patentee has five times more incentive to prevail in litigation than any one challenger has.' ibid. 
paying non-discriminatory royalties as challengers often find themselves subject to injunctions or less favourable licensing terms. Patentees can also charge differential royalties to penalise firms that do not settle early, all of which weaken the infringer's incentive to challenge in the first place. ${ }^{92}$

Recent litigation in the UK demonstrates how a simple legal arrangement can further skew incentives to litigate. Following a decision to overturn a patent that was previously found to be valid, a defendant had to pay damages on a patent that was held invalid and revoked in a subsequent decision. ${ }^{93}$ Understandably, the defendants in the original action contended that it would be 'monstrous' if they were ordered to pay an enormous sum in respect of a wholly non-existent right.

Under UK law the decision on validity and liability for infringement had already become final, and only the inquiry into the damages payable remained to be considered. ${ }^{94}$ Although such an inquiry in fact takes time, for all legal consequences it may be supposed to be instantaneous and to take place when the judgment is pronounced. ${ }^{95}$ The principal reason for such finality of outcome is to discourage defendants who having lost a patent action, motivate another party to attack the patent and dig up better prior art that could potentially invalidate the same patent and with a view to getting the defendant off the hook of damages. This kind of problem is an inherent feature of patent litigation because a patent is good against the world and therefore revocation is in rem and 'any person' can challenge a patent.

Given that invalid patents are a deadweight loss on society, it is desirable to keep the door open for further invalidity actions. Abuse of process would be rare because of the nature of patent litigation and the 'uniquely life sapping horror' 96 that it often represents. A defendant is unlikely to reserve his best piece of prior art for the next set of litigation when he stands to gain by revoking and being able to use the invention as soon as possible. The strength of patents as property rights depends on the efficacy of the litigation process, and maintaining the correct

\footnotetext{
92 ibid 12 (footnotes omitted).

93 The patent related to the laying of flexible conduits on the seabed relevant to the offshore oil industry. In 1996 Coflexip sued Stolt for patent infringement. In the first-instance trial Mr Justice Laddie held the patent valid and infringed. The decision was upheld by the Court of Appeal in 2000 and leave to appeal to the HL was not granted. Hence, the decision of the CA was final as far as Coflexip and Stolt were concerned. An inquiry into damages was ordered with Coflexip seeking approximately $f 80$ million. Following this a third party Rockwater, brought revocation proceedings relying on prior art which was not cited by Stolt in the previous proceedings. At trial the patent was held invalid and revoked. Following this Stolt applied for a stay of the inquiry as to damages. Justice Jacob refused a stay which Stolt took on appeal to the Court of Appeal. Cf Coflexip v Stolt Comex [2004] FSR 7 (Ch (Pat Ct)) and [2004] FSR 34 (CA).

94 The long-standing case of Poulton v Adjustable Cover and Boiler Black Co was followed by the Court of Appeal where in spite of a subsequent order for revocation of the patent defendants were bound by the earlier decision and had to pay damages [1908] 25 RPC 29 (CA), 661.

95 The main difference with US law is with respect to finality. There, the decision as to validity of the patent in suit is not regarded as final until 'conclusion of the accounting': Mendenhall v Barber-Greene Co 26 F 3d 1573 (Fed Cir 1994). Neither of the parties was able to find a case dealing with what would happen in parallel circumstances in any EU jurisdiction.

96 W. Cornish, Intellectual Property: Omnipresent, Distracting, Irrelevant (Oxford: Clarendon Law Lectures, Oxford University Press, 2004) 6, fn 9.
} 
balance of incentives to litigate. Coflexip seems to have further tampered with this balance. As the dissenting opinion notes:

anyone not possessed of a strictly legalistic turn of mind would think it most unjust that Coflexip should be entitled to receive, and Stolt required to pay, tens of millions of pounds for infringements of a revoked patent, simply because Stolt, through misfortune, poor judgement or ineptitude failed to find the crucial prior art which has now been established as justifying the revocation of the patent. ${ }^{97}$

In the US, litigation involving that ubiquitous technology product the Blackberry, highlights the unique shortcomings of patent litigation in weeding out property rights on invalid patents even where large sums of money are involved. A number of patents of US licensing company NTP Inc, relating to radio frequency wireless text communication was held infringed by Canada-based RIM (Research in Motion $)^{98}$ which runs the Blackberry service. A final injunction in favour of NTP would have forced RIM to shut down the Blackberry email service affecting millions of customers in the US.

Following a director-initiated inter partes re-examination by the USPTO, several of NTP's disputed claims were rejected. ${ }^{99}$ Nonetheless, a settlement was reached in March 2006 where RIM paid 6.12 million US dollars to NTP in an outof-court settlement; an outcome which the Judge in this case seemed to encourage. 100 The invalidity of some of NTP's claims did not prevent the early settlement because the patents remain valid until a final decision could be taken on NTP's patents - a process that was projected to take years just at the patent office. 101 Clearly, any 'evolution to efficiency' argument needs to be made within the context of institutional efficacy and competency particularly as in the case of patent litigation, institutions often function under a patchwork of constraints.

Litigation in the patent system ensures that the preservation of irrational patent doctrine is a real possibility. One key example is the survival of the non obviousness doctrine in In re Deuel in the US patent system. ${ }^{102}$ According to this

\footnotetext{
97 [2004] FSR 34 (CA), per Neuberger LJ (dissenting) at [86]. The majority seems to take the question of ineptitude on the part of Stolt in missing a crucial piece of prior art very seriously: [150].

98 NTP, Inc v Research in Motion, Ltd 418 F 3d 1282 (Fed Cir 2005); see also NTP, Inc v Research in Motion, Ltd 393 F 3d 1336 (Fed Cir 2004).

99 The ruling is described as an 'Action Closing Prosecution' by the USPTO. The ruling, although widely reported in the news and on specialist websites is not available from the web pages of the USPTO $<$ www.uspto.org> accessed 10 October 2008. See RIM Press Release 'RIM Provides Update on Patent Reexamination proceeding' 1 (February 2006) < http://www.rim.com/news/press/2006/pr-01_02_200602.shtml> accessed 10 October 2008

100 At the final injunction hearing Judge James Spencer of the Eastern District Court of Virginia, expressed surprise that both parties had left this 'important and significant decision' to the court. S. Bodoni, 'Blackberry Saga Boosts Case for Patent Reform' (April 2006) MIP 8-9.

101 RIM Press Release, 'Research in Motion and NTP Sign Definitive Settlement Agreement to End Litigation' (3 March 2006) < http://www.rim.com/news/press/2006/pr-03_2006-01.shtml> accessed 10 October 2008

10251 F 3d 1552 (Fed Cir 1995). Also see Phillipe Ducor Patenting of Recombinant DNA Products (Kluwer
} 
case a novel chemical is nonobvious if there are no structurally similar compounds in the prior art. Proteins are not structurally similar to the DNA molecules. The fact that a person skilled in the art could have used known methods to isolate the DNA sequence from amino acid sequence was, according to the court, irrelevant to the enquiry as to whether the DNA sequences themselves were inventive.

Remarkably, this interpretation sustains in the USPTO Utility Examination Guidelines $2001^{103}$ despite the well-recognised rift in scientific and legal perception. ${ }^{104}$ The Committee on Intellectual Property Rights in Genomic and Protein Research and Innovation of the US National Research Council makes a telling observation on the institutional nurture of this outcome:

[b]ecause it makes it easy for patent applicants to get past the nonobviousness hurdle, they have no incentive to challenge the rule, and after being repeatedly reversed on this point, the USPTO seems to have little interest in raising it again, even though advances in the art may culminate in a different result. ${ }^{105}$

Clearly, in the patent system it is difficult to reverse 'sub-optimal' outcomes through litigation. When coupled with the desire for legal certainty, it results in a status quo bias for legal doctrines - once they emerge they are likely to be tenacious.

\section{CONCLUSION}

Increasing returns processes may impact on patent law in a number of ways. When a question is first raised in litigation, new legislative measures are put in place, or unprecedented technology is presented to the patent office in patent applications, a number of legal interpretations of a particular provision are often possible. In such early contexts relatively small events, if they occur at the right time can have large and enduring consequences on legal doctrine. 'Because earlier parts of a sequence matter much more than later parts, an event that happens 'too late' may have no effect. Although it might have been of great consequence if the timing had been different.' Once an increasing returns process is established positive feedback will lead it to a single point that is resistant to change. As a

\footnotetext{
International 1998).

103 USPTO Utility Examination Guidelines 66 Fed Reg 1092 (2001).

104 'On the one hand, based on prior art knowledge, the biotechnologist knows that sequencing around twenty amino acids is sufficient to obtain the cDNA sequence that codes for a particular protein, absent unforeseen difficulties. On the other hand, under current law, the expected product of this scientifically obvious manipulation is legally unobvious and thus patentable. Such a convoluted result is unsettling.' A. Varma and D. Abraham, 'DNA is Different: Legal Obviousness and the Balance Between Biotech Inventors and the Market' (1996) 9 Harv J L \& Tech 53, 78.

105 Committee on Intellectual Property Rights in Genomic and Protein Research Innovation, National Research Council, 'Reaping the Benefits of Genomic and Proteomic Research: Intellectual Property Rights, Innovation and Public Health' (National Academies Press, 2006) 70.
} 
positive agenda increasing returns and path dependence allows us to identify the sources of stability and change. In particular it highlights the meshing of interests and authority in the institutional cluster that makes up the patent system the centre-piece of which is the powerful agenda-setting role of patent offices.

In using the framework presented here to choose and analyse legal doctrines, several points of caution apply. Conditions conducive to positive feedback are of differential importance throughout the life of legal doctrine. Thus increasing returns may be more prominent during formulation of a policy rather than when it is operationalised and institutionalised. And not all sub-optimal outcomes will be the result of increasing returns processes. Further, analysis must be able to distinguish between the positive feedback driven by institutional factors and the impact of legal precedent. Often legal precedent only becomes an issue when the law is settled and there are clear and consistent decisions that can be followed. Increasing returns is likely to be important in the time before such precedents are set.

Nearly all of the literature on patent law doctrine is rational-actor based; however prominent and inter-connected sources of increasing returns in the patent system show the fallacy of assuming information about goals or criteria when it comes to formulating legal doctrine. Normative generalisations about what should happen are undercut by the dynamics of stability and change. A consequence for legal doctrine is that if we leave the unwieldy patent system to water-like 'find its own level', it is more likely than not to result in unintended, unforeseen and at times bizarre, doctrinal outcomes.

This paper explains continuity in the patent system while acknowledging implicitly that sometimes policies do change course and direction. Although the costs of policy change in the patent system grow and grow and become prohibitive, the possibility of policy reversal suggests the presence of political actors, institutions and policies that alter incentives and thus push for policy reversal. 106 On occasion the US SC and the House or Lords do change course; and European Commission led Directives fail. Additionally actors who get little for their efforts may over a period of time become available to reinforce coalitions that push for change - a phenomenon described exceptionally by Shadlen. ${ }^{107}$ The actors, features and critical timing of such policy reversal promises to be a fruitful avenue for future research and has to follow from a theoretical study of the relationship between path dependence and conditions of change. What this paper has tried to do is to analyse continuity and the scarcity of change in the patent system in the face of widespread increasing returns and critically comment on its impact on the quality of legal doctrine.

\footnotetext{
106 Autonomous institutions that can trigger change have to be designed to be less subject to reinforcing processes, such as for example the NIH. See Thambisetty 'Institutional Nature of the Patent System'.

${ }^{107}$ K. Shadlen 'Revolution, Reform, and Reinforcement: Three Waves of Response to the Globalization of Intellectual Property Rights', in S. Haunss and K.C. Shadlen (eds), The Politics of Intellectual Property: Contestation over the Ownership, Use, and Control of Knowledge and Information, (Edward Elgar, 2009 forthcoming).
} 